\title{
IAMJ
}

INTERNATIONAL AYURVEDIC MEDICAL JOURNAL

\section{A CONCEPTUAL STUDY OF SNAYU W.S.R. TO ANKLE SPRAIN (GULPHA)}

\author{
Archana Saroj ${ }^{1}$, Arvind Kumar ${ }^{2}$ \\ ${ }^{1}$ MD Scholar, ${ }^{2}$ Lecturer \\ P.G. Department of Rachana Sharir, State Ayurvedic College and Hospital, Lucknow, Uttar Pradesh, India
}

Corresponding Author Archana.jpsaroj@gmail.com

\section{https://doi.org/10.46607/iamj1809052021}

(Published Online: May 2021)

Open Access

(C) International Ayurvedic Medical Journal, India 2021

Article Received: 24/04/2021 - Peer Reviewed: 06/05/2021 - Accepted for Publication: 15/05/2021

Check for updates

\begin{abstract}
In Ayurveda, the role of Acharya Sushruta is very important. Acharya Sushruta was not only one of the earliest pioneers of surgery in the world but also one among the earliest to study the human body. Acharya Sushruta was the first in the field of Ayurveda who has defined the clinical importance of structural components of the body like Asthi (Bones), Jala (plexus), Kurcha (brush like structure), Sira (vein), Dhamni (artery), Snayu, etc. Snayu is one of the important anatomical structures in the human body which is strong and holds all the joints for the purposeful function. Similar to Snayu, in modern anatomy, ligaments and tendons are described as human structures which are attached bone to bone and muscle to bone respectively. All the joints are bound together by Snayu. According to shape and location the Snayu are of four types: Pratanvati, Vritta, Sushira \& Prithula. Snayu are very much similar to ligaments, so excessive stretching, tearing or injury to ligaments causes severe pain. Ligament injuries are the most common amongst the athletes or sports person. Common ligamental injuries are to the knee, ankle, wrist, thumb, neck or back ligament with ankle injury being the most common occurring injury.
\end{abstract}

Keywords: Snayu, Ligaments, Injuries. 


\section{INTRODUCTION}

Sharir Rachana is one of the basic subjects for the principles of Ayurveda. Acharya Sushruta in Sharirsthan has described the anatomical position of various structures, Snayu being one among them. The strength of the body depends upon Snayu, Asthi, Mamsa, etc. Snayu is an important structure which binds the Mamsa (muscle) and Asthi (bone) in the body thereby helping in weight bearing. In Ayurveda literature, Snayu has been also considered as Vatavahanaadi. It may be the reason that injury to this structure leads to severe pain when compared to any other structure in the body. The reason for it can be considered as pain is merely due to vitiation of Vata and without Vata there is no pain. Sandhi (joint) is important for locomotion and other vital functions. The strength of the joint depends upon Snayu, Asthi (bone) and Mamsa (muscles). Snayu maintains the stability of joints during movement of the body. Any traumatic injury to the joint causes severe pain, swelling, sprain and improper movement of the joint. Sprain is commonly caused by excessive stretching of ligaments and is classified into first, second and third grade respectively. The most common type of foot and ankle injury is ankle sprain.

Vyutpatti: The word Snayu is formed from the word root (Dhatu) 'Sna'. 'Sna' Dhatu when combined with ' $u n$ ' and 'yuk' Pratayaya forms the word Snayu.

\section{Historical Review:}

Acharya Charak has enumerated Snayu as Jangam Dravya along with the other Dravya like Madhu, Goras, Vasa, Majja, Rakta, Mansa, Mala, Mutra, Tvak, Asthi, Horns, Nails, Hair, Roam and Gorochan. Acharya Sushruta has described Snayu as a suturing material for the Vrana in 25th chapter of Sutrasthana in Sushruta Samhita.

Acharya Dalhana has stated that Mahasnayu is Kandara. According to Acharya Dalhana, the Snayu resembles the shape of Shanakar refers to a group of fibers used for making a cord. It also implies for making string of the bow. Acharya Sharangdhar stated that Snayu are the binding material used for binding Mamsa, Asthi and Meda. Acharya Chakrapani has given a brief description about Snayu, Sira etc. as binding structure in the body. In Parishadya Shabdartha
Shariram, the term Snayu is explained in detail and in a more scientific way. In Pratyaksha Shariram, Acharya Gannath Sen has described Snayu as a dense bunch of Shana (also referred as cord fibers) meant to bind the Sandhi.

According to Kashyap Samhita, Snayu is termed as Mastulunga Moola whereas in Sushruta Samhita, Mastulunga has been explained as a type of Medas.

\section{Utpatti Of Snayu:}

Acharya Sushruta in the $4^{\text {th }}$ chapter "Garbha Vyakaran Sharir" of Sharir Sthana in Sushruta Samhita has described that the formation of Snayu in foetus is the result of the Khara paka of meda dhatu by pitta (Tejas).

\section{Snayu Sankhya:}

According to Acharya Sushruta, in the 5th chapter of Sharir Sthana in Sushruta Samhita, the total no. of Snayu are 900 in number out of which 600 in Shakha, 230 in Koshtha and 70 in upper part of Jatru. According to Ashtang Sangraha, there are 900 Snayu in human body. Acharya Charak has also described that Snayu are 900 in number.

\section{Snayu Bheda (Types of Snayu):}

i) Pratanvati: are branched and tendril like structure. These are present in all the Shakha (extremities) and the Sandhi (joints) of the body.

ii) Vritta: These are rounded or cylindrical in shape. According to Dr. Bhaskar Govind, Ghanekar Vritta is considered as Kandara which is also present in extremities and in all the joints of limbs.

iii) Sushira Snayu: is found in Amashaya (stomach), Pakwashaya (large intestine) and Vasti (urinary bladder) and are porous like structure.

iv) Prithul Snayu: are thick or flattened and sheet like structure in shape. It is present in Parsva (flanks), Uras (chest), Prishtha (back) and Shir (head) of the body.

\section{Importance of Snayu}

- Acharya Sushruta has also described the importance of Snayu that injury to the bones, muscles, veins nor joints does not kill the person whereas injury to Snayu can be a lethal one and can kill a person. 
- A boat consisting of planks becomes capable of carrying load of passengers in river only when it is tied properly with bundle of ropes. Similarly, when all joints in the body are tied with many ligaments then only the person's body is capable of bearing load.

Snayu Marma: Acharya Charak has concised Marma only from the medical point of view while Acharya Sushruta who belonged to school of surgeons, elaborated information about every Marma in the body as available in Sushruta Samhita. There is a total of 107 Marma in the body. These Marma are Panchatmaka (five types) e.g. - Mamsa Marma, Sira Marma, Snayu Marma, Asthi Marma, Sandhi Marma in which Snayu Marma are 27 in number. These are 4 Aani, 2 Vitapa, 2 Kakshadhara, 4 Kurcha, 4 Kurcha Sira, 1 Vasti, 4 Kshipra, 2 Amsa, 2 Vidhura, and 2 Utkshepa. Snayu Marma are the specific vital points where Snayu predominance occurs.

Ayurveda view of Gulpha: In Ayurveda the ankle is called Gulpha which is derived from "gal" dhatu (root) "Fuk" prateya (affix). Gulpha is that part of the body where the foot is connected to the leg. According to Dr. Ghanekar Gulpha is ankle joint.

Gulpha Marma is situated at the junction of Pada (foot) and Jangha (leg). Gulpha Marma is Shakhagata Marma. It is 2 in number one in each lower limb. Acharya's have explained its dimension as 2 Angula. Trauma to this Gulpha Marma causes pain, restricted movement and limping.

Ankle Sprain: Snayu may be ligament, tendon, aponeurosis or sphincter muscles but ligaments are appropriate structure for the term Snayu depending on the shape and function. Snayu, which are present in Shaka (limbs) and all Sandhi (joints) of the body are termed as ligament. Ligaments are fibrous band connecting the adjacent bones and forms on integral part of the joints. Ligamental injury in ankle joint is termed as ankle sprain and is also known as twist ankle or rolled ankle. It is one among the most common occurring injury to sportsperson, athletes, laborers, etc.

Relevant anatomy of Ankle Joint: The ankle complex includes three joints.
I) Talocrural (ankle joint): It is synovial hinge joint between Tibia, Fibula and Talus inferior tibiofibular joint and unites tibia and fibula into mortise.

ii) Subtalar Join: Synovial joint between talus and calcancus is divided into anterior and posterior articulations which are separated by the sinus tarsi.

iii) Inferior Tibiofibular Joint: Distal parts of the fibula and tibia articulate to form fibrous inferior tibiofibular joint (tibiofibular syndesmosis).

\section{Anatomy Review of Ligaments:}

There are three sets of ligaments to stabilize ankle complex:

- Lateral collateral ligament.

- Medial collateral ligament.

- Distal tibiofibular syndesmotic complex.

1. Lateral Collateral ligament: It stabilizes ankle against inversion:

a) Anterior Talofibular ligament (ATFL).

b) Calcaneofibular ligament (CFL).

c) Posterior Talofibular ligament (PTFL).

d) Lateral Talocalcaneal ligament (LTCL).

2. Medial Collateral ligament: it is also called deltoid ligament and is the strongest ankle ligament.

3. Tibiofibular syndesmotic ligaments: it maintains the width of ankle mortise and stabilizes against eversion.

\section{Classification of Ankle Sprain}

1. Low ankle sprain: It is called lateral ankle sprain (classic sprain) 80 to $85 \%$ in which most common mechanism of ankle injury is inversion of the planter flexed foot. The anterior talofibular ligament is the first or only ligament to be injured in most ankle sprains.

2. High ankle sprain: It is also called syndosmotic sprain. There generally tends to be less swelling with a high ankle sprain, however, there tends to be pain that's more severe and long lasting. It is more likely to result in recurrent sprain.

Grading for Ankle Sprain: Ankle sprain has been classified into 3 grades:

1. Grade one: It results from mild stretching of a ligament with microscopic tears.

Patients have mild swelling and tenderness. The patient can bear weight. 
2. Grade two: Is more severely injury involving an incomplete tear of an ankle ligament. Patients have moderate pain, swelling, tenderness and ecchymosis.

3. Grade three: Involves complete tear of ankle ligament. Patients have severe pain and tenderness in ankle. Patients are unable to bear weight.

It is estimated that $80 \%$ to $85 \%$ of ankle sprains/tear occur to the lateral ligament.

\section{DISCUSSION}

Acharya Sushruta has classified the Snayu into four types: Pratanvati, Vritta, Sushira and Prithul. According to Acharya Ghanekar, Pratanvati Snayu are ligaments and Vritta are tendons. Sushira Snayu are found in hollow organs while Prithul Snayu are flattened in shape and called aponeurosis are found inside, chest, head and back. Acharya Sushruta has said that Pratanvati Snayu is found in Shakhas and all the joints of the body. Dr. Ghanekar and Damodar Sharma Gaur have stated that Pratanvati Snayu which is considered as ligament, provides the articulating sites. They firmly hold the articulating ends of the bones together and facilitate the joints to be more movable in various directions.

During the etymological review, we came across a few instances that Snayu is a structure which binds the Anga Pratyanga Sandhi (joints). Etymologically Snayu is considered as a structure which performs the function of holding and binding the various structures of the human body like bones, muscles and adipose tissue. According to Ayurveda Snayu is a "Shan" (fibrous) like structure. Ligaments, tendons, Aponeurosis, fascia and other fibrous structures in the body fits into above description. A review of contemporary science reveals that Mamsa (muscle) are bound to the bones by ligaments and tendons. Bones are bind together at each joint by ligaments. In general, the function of fibrous structure in a human body is to bind the body structures intact to have the ability to move bearing its own weight as well as bearing the extra weight. It should be a very strong structure so that it holds the bones and muscles together. It must be present around the joints as bones are held together, so the term Snayu literally means to bind. It is also explained as ligaments attach the bones at either ends. Ligaments and tendons are quite similar but differ in the way they are attached. Ligaments attach bone to bone and tendons attach bone to muscle. In Ayurveda literature Snayu is defined as Vatavaha Nadi also and Vata is responsible for any type of pain in the body. It may be the reason why injury to Snayu leads to severe pain compared to any other structure in the body. Pranavayu which is in Murdha (head) may be travelling through Snayu throughout the body.

Anatomically Pratanvati Snayu is like the ligaments which are fibrous thread like structure are present in joints and connects the adjacent bones. Ligament is the strong fibrous band which connects bones especially at joints. Ligament injury called sprain occurs when ligament is stretched beyond its normal limit. Symptoms of sprain are same as the symptoms of vitiated Snayugata Vata specially Pratanvati Snayugat Vata like stiffness, severe pain, restricted movement and sprain. Ankle sprain is the most common sprain. Sprain is classified according to its severity. It is classified into three grades e.g. first grade, second grade and third grade.

\section{CONCLUSION}

Snayu is considered as a binding structure which performs the function of holding and binding of various structures like bones, muscles, and adipose tissue. Snayu may be ligaments, tendons and aponeurosis or sphincter muscles. Ligament connects bone to bone and tendons connect bone to muscle. Sushir Snayu is ring like structure and is present in hollow organs called sphincters. Prithul Snayu is flattened in structure and is correlated with aponeurosis connecting muscles to bones. But as per the ancient literature, Snayu on the basis of function and structure, are more appropriate and closer to the ligament which is defined as Sineu or thread (fibrous) like structure.

Snayu is also defined as Vatavaha Nadi in ancient literature, so any injury in Snayu is very painful and unbearable because any type of pain is the nature of Vata. Ankle injury which is most common ligamental injury also called ankle sprain can be prevented by maintaining regular physical fitness or conditioning programs like stretching and strengthening exercise or activity. So, it is very important for the physicians, doctors and 
surgeons to have a complete understanding about the knowledge of Snayu.

\section{REFERENCES}

1. Shastri Ambikadutta, Sushruta Samhita Part-1, Reprint 2007, Chaukhambha Sanskrit Sansthan, Varanasi, Sharirsthan, Chapter 6, Verse 3-7, Page 50-51.

2. Joshi Sunil Kumar, Marma Science and Principles of Marma Therapy, $1^{\text {st }}$ Edition 2010, Vani Publications Delhi, Page 102.

3. Shastri Ambikadutta, Sushruta Samhita Part-1, Reprint 2007, Chaukhambha Sanskrit Sansthan, Varanasi, Sharirsthan, Chapter 6, Verse 12-13, Page 52.

4. Sharma Priyavrat, Charak Samhita Vol.-1, Edition 2014, Chaukhambha Orientalia Varanasi, Sutrasthan, Chapter 28, Verse 21, Page 229.

5. Sharma Priyavrat, Charak Samhita Vol.-2, Edition 2014, Chaukhambha Orientalia Varanasi, Sutrasthan, Chapter 28, Verse 35, Page 463.

6. Srikanthamurthy K.R., Sushruta Samhita Vol.-1, Edition 2004, Chaukhambha Orientalia, Varanasi, Nidansthan, Chapter-1, Verse 27, Page no. 465.

7. Srikanthamurthy K.R., Sushruta Samhita Vol.-1, Edition 2004, Chaukhambha Orientalia, Varanasi, Sutrasthan, Chapter-25, Verse 37, Page no. 187.

8. Shastri Ambikadutta, Sushruta Samhita part-1, Reprint 2007, Chaukhambha Sanskrit Sansthan, Varanasi, Chikitsasthan, Chapter 4, Verse 8, Page 26.

9. Chaursaia B.D., Handbook of General Anatomy, $4^{\text {th }}$ Edition 2009, edited by Krishna Garg, CBS Publishers \& Distributors Pvt. Ltd., New Delhi, Page 198.

10. Snell S. Richard, Clinical Anatomy by Regions, $8^{\text {th }}$ Edition 2009, Wolters Kluwer pvt. Ltd., New Delhi, Page 15-17.

11. Thesis- Dr. Arvind Kumar "A Surgico Anatomical Study of Snayu Marma"- 2001. Page No. 1.

12. Thesis- Dr. Vijendra Pratap Singh "A Study of Applied Anatomy of Snayu w.s.r. to Pratanvati Snayu." 2016. Page Nos 166, 167, 168.

\section{Source of Support: Nil \\ Conflict of Interest: None Declared}

How to cite this URL: Archana Saroj \& Arvind Kumar: $\mathcal{A}$ Conceptual Study Of Snayu W.S.R. To Ankle Sprain (Gulpha). International Ayurvedic Medical Journal \{online\} 2021 \{cited May, 2021\} Available from: http://www.iamj.in/posts/images/upload/1054 1058.pdf 